\title{
BLOCKCHAIN USE CASES EXPLORATIVE STUDY FOR INDIAN AUTOMOTIVE INDUSTRY
}

\author{
Paritosh Dhondiyal \\ Automotive Professional, B.Tech-MBA \\ Pune, Maharashtra, India
}

\begin{abstract}
Blockchain technology that has numerous benefits like immutability, finality and consensus is expanding its footstep in industrial world. Many countries and industries has started its initial usage and now Government of India has also shown interest to utilize its potential barring its usage with crypto transactions and piloted prototypes in registry of land records, health care etc. Sooner or later the technology will impact the Indian auto industry as many global auto players has started various initiatives based on blockchain, however the decision to use technology has to be driven with rationale and business logics rather than herd mentality. Many use cases has been theorized, forecasted, prototyped and implemented by industry and researchers on this technology. Blockchain along with IOT, AI and big data has potential to transform the way industry operates and has application potential across all sectors and functions. The analysis and conclusion reveals that automatic software update is one of the use case of block chain technology where Auto Industry can immediately work upon. Other conclusion that is drawn is use cases related to supply chain, traceability, targeted recalls, smart manufacturing, extended vehicle ledger, connected services, smart, EV segregated aggregate shall be reviewed after three years ,uses cases related to shared fleets/mobility as a service, asset registry, automatic transactions/cross border payments, finance, regulatory compliance, dealer and customer incentives, odometer fraud and warranty handling to be reviewed after span of five years and futuristic use cases of smart grid interoperability, retail and digital retailing and communication in autonomous vehicles to be reviewed after seven years.
\end{abstract}

Keywords - Automotive, traceability, software, vehicle ledger, automatic transactions, asset registry, regulatory compliance, warranty, recall

\section{INTRODUCTION}

Block chain in the new technology buzzword in the industry and researchers and Industry consultants has forecasted it as next disrupter in the business. Block chain was first implanted in 2008 by a pseudonym Hashimoto Takemoto which could be an individual or group pf Individual in the field of cryptocurrency "bitcoin" (Sowichaya Supranee, 2017) (Zibin Zheng, 2018). Block chain in Simple words is a decentralized public ledger, where all transactions are stored in blocks and when new transactions are added to it the chain grows. These blocks are stored at same time in peer to peer network. Blockchain removes friction, reduces risk by enabling the near real-time settlement of recorded transactions. As this technology is based on principles and trust of cryptography and peer to peer network, it removes the need of third party and two hence two parties can transact directly. The peer -topeer networks enables recording a public history of transactions. As the block chain contains verified record of every single transaction at each node hence this ledger is irreversible and immutable and hence no abuse, manipulation, fraud can be done. Pre-defined legally enforceable business procedures called smart contracts can also be defined in block chain that can be executed without involvement of third party (Zibin Zheng, 2018). There are three different types of blockchain i.e. public, private and consortium blockchain with the latter two for industrial usage. Hyperledger project was kicked off by Linux Foundation to provide an open source platform for industrial application. This project is funded by almost all Industry majors like Boeing, IBM, Daimler etc. (https://www.hyperledger.org, 2017). Bitcoin a cryptocurrency is the most famous application of blockchain application, but it can be applied in many diverse applications in conjunction with IOT, AI, Big data etc. Globally, amongst enterprises, block chain revenue is concentrated in 3 key industries: banking, manufacturing and services. Manufacturing is second most expected industry to make use of block chain. Industry consultants like Deloitte, Accenture, and Capgemini have forecasted use cases and have also developed and commercialized business solutions on the same. On similar lines many researchers have also forecasted use cases in Industry like EV battery swapping, supply chain automatic software update etc. Many uses cases like traceability in supply chain, Tracking provenance of parts, supplier contract management, digital thread, anti-counterfeiting, security, product recall (Sudhir Pai,Manuel Sevilla, Jerome Buvat,Ralph Schneider-Maul,Olivier Lise,Adrien Calvayrac,Tarun Karanam,Ramya Puttur, 2017), supply chain and its integration with manufacturing, fractional ownership model of vehicles (Brody Paul, Schartau Philip, 2018), Digital services in Automotive ecosystem. (Schade Martin, Pytel 
Philipp, 2017). Niti Aayog have piloted prototypes on pharmaceutical supply chain for identification of spurious drugs, fertilizer supply chain eliminating subsidy leakage and digitization of land records. (Niti Aayog Recomends use of blockchain in land records, PDS and Healthcare, 2019) and various state governments in India are also working on the technology with service providers. Various Auto Giants like GM, Ford, Renault and many others have already ventured in blockchain applications. Worldwide different countries have adopted different approaches towards the technology.

Automobile companies in India today do not have deep insights of blockchain technology and its potential applications in automotive business. Indian automotive business environment is becoming tougher day by day due to hyper competition in the market, availability of alternate mobility solutions, vehicles getting complicated due to increasing electronics and software contents in vehicles and regulations evolving at fast pace. To have a competitive edge at the market place it is necessary to have a complete overview of current and emerging technologies, their impact on business process, application areas, automotive use cases and regulatory framework. Blockchain is one of emerging technologies and hence it is necessary to have an insight on it .This study is done to provide basic insights of the technology .This study provides basic understanding of business logic that decides the application of blockchain technology in a business process use case .This study also provides an overview of probable areas of application of blockchain technology in business process of automotive companies with a timeline roadmap where technology use case is recommended to be immediately explored for further feasibility and implementation or reviewed in future backed by qualitative rationale.. In this study data is collected through primary sources mainly write-ups by industry consultants, research papers, and data of Global OEMs in public domain to understand the potential areas of blockchain usage by auto companies. Interview conducted with lead users of the technology provides deep insight on decision criteria to use blockchain technology as a solution and same is utilized to conclude on particular use case.

Technological introductions in the business environment and society has always brought a radical change in the way world operates. Those who are ahead in decision making curve and make a correct decision have a competitive edge over the competitors and those who take wrong decisions while implementing any technology based on herd mentality suffer the losses. Blockchain is one of these technology where at one side it is forecasted as one of the industry disrupter (White, 2017) and on other side its implementation is yet to pick up momentum. Blockchain technology which is a distributed ledgers was first used by Satoshi Nakamoto a virtual user/group for crypto currency Bitcoin where all records were kept in ledgers available (Blockchain Technolgy : Implications for operations and supply chain management) in different nodes of a network. In a central ledger, central authorities transfer actual value between two parties and multiple intermediaries are required to facilitate transfer of assets and create trust hence central ledger is expensive, it has manual interventions for record matching, it is inefficient and time consuming, it involve resources and is vulnerable and prone to attacks. On the other hand blockchain distributed ledger keeps records in distributed nodes and maintain a shared source of information. Trust is enabled by cryptographic algorithm that provides single source of truth, finality, immutability, consensus and provenance, with provision of smart contracts that can be executed with in build smart logics.

5.2 Block chain Basics: "A block chain is a digital, immutable, distributed ledger that chronologically records transactions in near real time." Block chain works on peer-topeer network where each transaction is stored in each nodes in form of blockchain. As the name blockchain suggests a transaction is stored in one block and subsequent transactions are added in the chain as another block and so on. Before the data is attached to each block, transaction is validated by participating nodes to endorse as valid transaction.

Block chain works on principle of cryptography where each unique input can be converted to unique Hash (\#) output. There are different hash output even for almost similar input. This input can be anything right from single letter to complete data of Wikipedia that can be converted into alphanumeric string and each string output is unique. shows concept where each data is attached in such a way that it forms a tree known as merkel tree with data in the root. Each block has hash of previous block, a time stamp, a merkel root and a nounce. Hence it is impossible to change, temper or modify a data as each block is connected through hash of previous block, and modifying all blocks is almost impossible. Moreover one have to change the data in all blocks of blockchain at all nodes at one point of time which makes it impossible to temper the data. Hence it is also an immutable distributed ledger. Blockchain has many benefits. It has information consensus across all the parties involved. This is made possible by sophisticated cryptographic authorization and verification mechanism that ensures trust in multi-party network. It also has time stamp that means the chronology of events are maintained. As there are secure encryption and decryption mechanism available, hence transaction with untrusted members can also be done. Digital signature ensures complete authenticity and non-repudiation. Business to business ownership of assets and provenance can also be tracked. As explained above, the architecture makes the network resilient and hence data loss becomes a non-issue. Because it works on peer-to - peer network, there is no need of any third party as a controlling agency. Smart Contracts which are sophisticated encrypted business logics can easily be built upon block chain that can be executed automatically once a transaction is validated.

Blockchain in Real world: There are three types of block chains. The first one is public blockchain where there are 


\section{International Journal of Engineering Applied Sciences and Technology, 2020 \\ Vol. 5, Issue 7, ISSN No. 2455-2143, Pages 83-101 \\ Published Online November 2020 in IJEAST (http://www.ijeast.com)}

many unknown participants with read and write permission to all and validation is done by consensus proof or work. The crypto currencies like Bitcoin and Etherium are example of this category of blockchain, These block chains have write permission to all, read permission to all, consensus by Proof of work. However there are limitations like less number of transactions due to slow speed and huge requirement of computing power and resources. The second category of blockchain is Private Blockchain which has known Participants from one organization, write permission centralized, read may be public or restricted, multiple algorithms for consensus. The third category of blockchain works as consortium blockchain which has known participants from multiple organization, write requires consensus of $n$ participants, read may be public or restricted, with multiple algorithms for consensus. Private and Consortium blockchain is more suitable for business applications. Hyperledger project initiated by Linux foundation to promote and make blockchain accessible to business world with open source technology. Leading Global organizations across sectors have recognized the business value of blockchain hence have funded the hyper ledger project. Example of companies associated with the projects are IBM, Airbus, Daimler, Cisco, SAP, Accenture, Intel, Accord, Hitachi, Fujitsu etc. Globally, amongst enterprises, block chain revenue is concentrated in 3 key industries: banking, manufacturing and is second most expected industry to make use of block chain by year 2022 followed by financial services (NASSCOM Avasant India Blockchain report 2019). Indian business ecosystem is in early stage of experimentation.

Global Scenario of block chain:52 countries are participating or have members observing development of blockchain standards with International Standards Organization (ISO).Approximately 40 countries have mandated licenses as a requirement for trading, sale of cryptocurrencies, operations of Initial Coin Offerings or Crypto exchanges. 26 Countries have a regulatory sandbox to enables startups to test their products with limited number of customers for a trail period where there are exempted from regulations. While most of the countries apply existing regulations to blockchain, 7 countries have developed regulations specific to distributed ledger technology. Japan has realized cryptocurrencies and these can be exchanged if they are registered with Japanese Financial service agency (NASSCOM Avasant India Blockchain report 2019). The investment done by venture capitalists in field of blockchain in year 2018 accounts for USD 3.17 billion which is more than the investment done in the last five years. In India the approach of Indian Government is cautious leading to very low investment done and is about 8.5 million USD in year 2018 hence Indian startups and Indian entrepreneurs are finding their ways towards countries like Malta, Switzerland, Singapore and UK where the regulatory framework is more conducive. Indian startups also find it difficult to be cited by global investor due to the cautious approach of Indian
Government and restriction of trading and conversion of cryptocurrencies with real currencies.

In India Although Approach of government is cautious till 2018, recent shift towards approach has been noticed since year 2018. Niti Aayog targeted following for first use blockchain technology in year 2018 .

- Land / Property registry, as two third of law suits pending in Indian courts are title suits.

- Supply management in public distribution system and pharmaceutical supplies to control subsidy leakage and fraudulent drugs control. (Year End Review 2018 :Niti Aayog, 12 , Dec 2018).

In 2019 proof of concepts were demonstrated by Niti Aayog. (Niti Aayog Recomends use of blockchain in land records, PDS and Healthcare, 2019). Future potential areas forecasted by Niti Aayog are EV battery swapping, Supply chain, Organic produced certificates, health records. As per the vision of Niti Aayog following are the top action areas .Govt. need to enable application of block chain by legal system change.

- India need skilled manpower and exploration if help to block chain companies

- India to be champion of block chain technology. (Aayog), 2018).

*Different Indian states have identified areas of usage of blockchain with land registry, farm insurance as top use cases

In Dec 2018 IBM institute of business value and Oxford Economics conducted survey on automotive domain. The views of Automotive Industry Professionals were asked about future of blockchain in automotive space. The results revealed that $62 \%$ of automotive executives are convinced that blockchain will be a disruptive force in automobile sector by the year 2021. Tt was also found that $54 \%$ of Auto companies are planning their first commercial block chain network at large scale within the next three years (ZIGURAT, 2018). Block chain applications are already in use in case of complex supply chain (Lakhani, 2017)

\section{Blockchain use cases in Industry:}

Following are the key use cases of block chain in Financial Sectors. ( Karanjla Binalfar, Laxman Shankar, Goswami Saurajit, 2017)

\section{Capital Markets.}

- Trade settlements: Securities and payments are transferred faster and trading cost are reduced as intermediaries are removed.

- Commercial Papers Issuance and Trading: Issuance and allocation of commercial papers and delivery and payment settlements to investors based on smart contracts.

$\underline{\text { Public Sector }}$ 


\section{International Journal of Engineering Applied Sciences and Technology, 2020 \\ Vol. 5, Issue 7, ISSN No. 2455-2143, Pages 83-101 \\ Published Online November 2020 in IJEAST (http://www.ijeast.com)}

- Digital Identity: Blockchain based, management of digital identity for near real time contract management of partners

- Customer On boarding: Digital identities are leveraged to improve customer on boarding. Banking Industry

- $\quad$ Trade Finance: Trade finance process are streamlined and shortened with minimum involvement of intermediary

- Regulatory Reporting and Compliance:

- Financial information are stored and manual audit errors are reduce and reporting costs are also reduced Insurance Industry:

- Underwriting: Identities are verified, completeness of applications are ensured, risk evaluated and complete quoting and binding is processed.

- Claims Processing: Smart contract based claim processing.

Smart Identity

- Redistributed ledger and smart contracts based identity management system for customers, agents and employee ecosystem.

Transfer Pricing

- Smart contract for solving process and information fragmentation alongside ensuring compliance with corporate governance and regulatory guidelines. Loyalty

- Blockchain usage for employee reward system and customer loyalty program. Reward points are traded as assets.

Blockchain use cases other than finance industry are

Oil and Gas digital supply chain

A Blockchain-based tracking of oil (asset) through the entire supply chain

- All events are recorded and viewed through the lifecycle in immutable ledger.

- Lease execution and termination are smart contract based that results in reduction in legal costs

- Enhanced financial management. Retail \& CPG: Warranty Receipts

Usage of chatbot to store warranty receipts on the Blockchain, to help

- Reduction in disputed between retailers and customers for lost receipts and unreadable receipts etc.

- Track history of ownership.

Telecommunication: Roaming Fraud

Smart contract based solutions aimed at

- Roaming contract based on call / event data are automatically triggered.

- Near instantaneous charging and reduction in roaming fraud
- Third-party clearing house are eliminated reducing the costs.

Public Sector: Land Registry

Blockchain based land registration system

- Costs will be reduced and errors will be eliminated in blockchain based transfer of ownership

Healthcare and life sciences: Patient Record Management

Blockchain based record management system to enable companies

- Simplify claim processing

- Secure medical records

- Monitor the Pharma supply stakeholders

Trade Finance

- Successfully executed transactions in international trade finance and remittance using Blockchain

Supply chain Financing

- Cloud-based application to transform supplier-tomanufacture trade finance transaction through a permissioned distributed ledger.

- Real time payments to suppliers based on blockchain based platforms.

- e-KYC Document Management

Management of KYC document of partners and participants.

Cross-border Payments

- Stellar has partnered with four financial in situations to enable low-cost global money transfer to the Philippines and cross-border payments to and from India, Europe, Kenya, Ghana and Nigeria.

Employee Loyalty / Rewards

- Deloitte India is working on Blockchain based rewards and recognition program.

Unique use cases of blockchain: There are many use cases of blockchain, however few unique ones are mentioned below.

- The World Wildlife Fund (WWF): "bait-to-plate" Tuna Project is implemented which is RFID and QR code based. This helps customers to know the source of the fish, till the level of fisherman who has caught the fish. On similar lines a London based NGO has developed a solution to trace yellow fin Tuna. Cap Gemini has developed a similar solution for traceability, provenance and connectivity of farmers and fisherman with high end restaurants. Similar solutions have huge potential in many sectors like pharmaceuticals, luxury goods etc. As an estimate $€ 966$ billion opportunity exists for brands to have transparent sustainability credentials (Sudhir Pai et al 2017). This opportunity is created as consumers are more aware and concerned about the traceability of products. (Sudhir Pai et al. 2017)

- A Startup in Australia has developed a platform on permissioned distributed ledger for anticounterfeiting of wine bottle exports.Similarly- 


\section{International Journal of Engineering Applied Sciences and Technology, 2020 \\ Vol. 5, Issue 7, ISSN No. 2455-2143, Pages 83-101 \\ Published Online November 2020 in IJEAST (http://www.ijeast.com)}

JD.Com (a Chinese Ecommerce giant) is combatting counterfeit products with a solution developed on hyper ledger platform. Within few months ten companies in field of alcohol, food, tea, and pharma registered to the platform. Deloitte Attractive is a platform for tracking authenticity of art works. Similar solutions have great potential in aeronautics, manufacturing, automotive as many cases of counterfeiting of products exists for example -In 2017, 500,000 counterfeit car parts were seized in a raid in Abu Dhabi. Blockchain based solutions have ability to trace parts. (Blockchain for the Automotive Insustry, worldwide survey results, 2017).

- Blockchain has potential to trace the environmental conditions during transportation of products. A combination of IOT sensors can update the temperature, humidity data on blockchain and customer can know all the environmental conditions that a product has gone through till final

- Blockchain potential can be easily extended to fractional ownership of vehicle. A vehicle can be broken down to different components like battery, powertrain. Each component can be tracked separately. Services like dynamic insurance can be implemented on blockchain. Separate spends on each component of vehicle can be tracked. Tokenized model of economy enables sharing of portion of car with connected users. ( Westland Duncan)

- Blockchain potential is extendable to digital services like automated payment of parking, fuel refilling etc. Dynamic insurance, service booking appointment can easily be built by smart contracts. A vehicle ledger can easily store the vehicle history right from the birth of the vehicle. (Schade Martin et al. 2017).

- Supplier contract management is another area where blockchain potential can be unearthed. Foxcon which is Apple Inc.'s largest subcontractor has launched a supply chain finance platform called Chained Finance to provide working capital to suppliers. A 6.5 million\$ loan was disbursed to suppliers in no time during the sandbox trial without keeping bank in loop. Similarly Deloitte Trace chain which is end-toend supply chain solution seamlessly order or sell, track and pay, create documentation update, view and verify on blocks. It also initiates automatic payments with smart agreements (e.g. between seller and customs authorities, seller and shipping company and between seller and buyer). Extended IOT sensors and smart devices also records the condition of shipments inform final settlements e.g. if goods have been damaged). (Sudhir Pai,et al. 2017).

- Use cases of product recall has been prototyped. Walmart's block chain pilot in China enabled them to trace a package of mangoes from store to farm in a few seconds. Previously, this would have taken days or weeks. Deloitte Trace chain is a blockchain based solution enabling car makers to identify specific vehicles that contain defective parts. Hence they can recall specific cars reducing less convenience to customers and also reducing cost of recall. In addition the solution can summarize how many defective vehicles have been recalled, that is normally asked by the regulatory bodies. (Blockchain for the Automotive Insustry, worldwide survey results, 2017)

- Even security systems has seen use cases of blockchain. The Government of Dubai has demonstrated a proof of concept of digital passports. This works on biometric verification with blockchain that creates a gate less border and through blockchain customer shares information through security officials and airlines. Only pre cleared passengers walking through biometric tunnel can cross the security gate. On similar lines London based ObjectTech have developed an application for digital passports where individuals can control the view access of the information. They can also chose to add extra details such as financial information, addresses and location from a mobile device. A scanning technology is used to scan the faces of people entering the airports. These uses cases have emerged as todays solutions are not foolproof, time consuming and manual. (Sudhir Pai et al.2017)

- In the field of electric distribution and electric mobility The University of Tokyo Toyota and Trende (electricity distribution company) working on future use case of electric vehicle ecosystem. Prototype has been made where battery of electric vehicle can be used as reservoir and connected through grid. Electricity can be sold when car is not in use. (https://www.automotivetestingtechnologyinternation al.com/news/rd/toyota-testing-electricity-system-thatuses-blockchain-technology.html, n.d.)

- In e-commerce market a blockchain platform known as Coup is designed to verify reputation of buyers and sellers. A hash is generated an uploaded in block with each single transaction like sale, purchase, claim registered, ticket raised, issue resolved etc. This information is useful for authorized users for future transactions.

- In the field of background verification applications are made so that fake resumes and CVs are not even entertained. This need has arisen from industry as despite of time consuming and costly background check there are many cases of employees with fake academic credentials emerge frequently. (https://appii.io/features/, n.d.) 


\section{International Journal of Engineering Applied Sciences and Technology, 2020 \\ Vol. 5, Issue 7, ISSN No. 2455-2143, Pages 83-101 \\ Published Online November 2020 in IJEAST (http://www.ijeast.com)}

\section{RESEARCH METHODOLOGY}

The study has followed following design approach.

\section{- $\quad$ Literature review -}

Basic Understanding of Topic, Legal political arena at global level and in the country, exploration of Use cases of the technology.

Review of Technical Papers/ Reports published by Industry Consultants like McKinsey, Earnest and Young, Deloitte, Cap Gemini etc. to find out the forecast, recommendations, models demonstrations of auto industry use cases.

Researchers forecast, demonstrations, models, on use cases for auto industry.

Use cases implemented, prototyped, and researched by auto industry globally.

\section{- Data Collection}

As this is exploratory research, interview is used as a tool to collect the feedback of lead user group, professionals (from companies, service providers etc.) who are working on blockchain technology to understand their views and insights on the use cases they are working upon. The interview questionnaire is framed and refined during first two three interviews. The main aim of interview is intended to understand why this technology is used for a particular business process and why not for other. What were the business logics decided the use of this technology? The interviews are summarized and collated.

Literature review, is the secondary source to find out the use cases by consultants and researchers for auto industry.

\section{Analysis and Interpretation:}

The use cases coming from interview is analyzed qualitatively to find the decision making criteria. For the analysis Eliyahu M. Goldrat matrix (pot of gold, Alligator, mermaid alligator 4 by 4 matrix) (Winson, n.d.) is used, along with business environment review.

The common use cases from voice of (consultants, researchers, Auto OEMs) is analyzed through Goldrat Matrix to analyze weather a use case makes a sense for business process of auto companies to immediately work upon adaptation of technology . Analysis also helps to understand whether it does not makes a business sense. Also the use cases can be kept on hold to be reviewed after a time period.

Conclusion: The Analysis is concluded as a summary with recommendations where auto companies should immediate work on the use case, and review the use case after some time

\section{DATA COLLECTION}

Through Secondary sources data collected. Collation of application areas/ use cases of blockchain recommended, forecasted, and prototyped and implemented by industry consultants (refer Annexure Table 6.1)
Researchers have documented their findings in the various published research reports and journals. (Annexure Table 6.2) represents the collation of use cases / application areas of blockchain technology as recommended, forecasted, and prototyped and implemented by researchers on this field.

Table 6.3 represents of collation of use cases / application areas of blockchain recommended, forecasted, and prototyped and implemented by Auto Companies

Key findings of interview with service providers/ lead users and experts who have explored and insights on the usage and feedback received (refer table 6.4)

\section{DATA ANALYSIS}

Common recommendations and use cases from researchers and consultants are clubbed in Table no.8.3 and uncommon use cases/recommendations ignored

Analysis of uses cases from Lead users/ service providers/ consultants done to find out the reasons of selecting blockchain as a solution, shown in tables (8.4 to 8.12 refer annexures)

Use case applicability analysis for auto companies in India and Conclusion:

Each common use case between consultants and Researchers (refer annexures table 8.3.1 to 8.3.13) are analyzed for its applicability in automotive business. In addition smart grid interoperability use case is also analyzed as it is the only use case from Auto OEMs that is not a part of use case in table 8.3 Few use cases are not considered for further analysis on Gold rat matrix as adequate conclusion is sought through prevailing business scenario as shown in Table 8.2.14

Following conclusions are drawn based on the analysis and interpretation

\section{CONCLUSION}

\section{Conclusion on business logic to adapt blockchain technology}

Blockchain technology has vast scope in almost all fields of business, however the selection of blockchain technology as a solution is mainly driven by government regulations and pull from the market as a customer preference. The implementation of blockchain solution is also dependent on ecosystem readiness which is not always in control of an organization, hence to unleash the potential of the technology industry consortiums are mostly needed. In India at present there is almost no pull from the market or government that is compelling the auto manufacturers and also the ecosystem to invest and implement the technology. However the technology has potential, Government has recently shown interest on the technology implementation and the trends observed worldwide will definitely impact auto industry in future and hence annually a close watch is further needed to see the 


\section{International Journal of Engineering Applied Sciences and Technology, 2020 \\ Vol. 5, Issue 7, ISSN No. 2455-2143, Pages 83-101 \\ Published Online November 2020 in IJEAST (http://www.ijeast.com)}

evolution of business scenario, Government regulations and pull from market for the technology.

Conclusion on use cases where Indian Auto companies should work, review in future:

Roadmap shown (refer annexure fig 9) concludes following Blockchain use related to extended vehicle ledger, connected services, EV segregated aggregate are shall be reviewed after three years. These use cases are regulations driven and hence an OEM can only keep a watch on evolving regulations and react to it.

-Blockchain use cases related to Shared Fleets/MaaS, Asset registry, Automatic transactions/cross border payments, finance, regulatory compliance, dealer and customer incentives, Odometer fraud and warranty handling to be reviewed after five years.

- Blockchain use cases of smart grid interoperability, retail and digital retailing and communication in autonomous vehicles to be reviewed after seven years as these use cases are applicable to future and needs to be proven first. Also the need will arrive in future only which depends on evolving market scenario.

\section{ACKNOWLEDGEMENT}

I sincerely acknowledge researchers, firms, organizations for their publications, white papers, presentations, research paper made available on public domains on blockchain technology, use cases ,regulations etc. Further I acknowledge the participants from lead users and technology service provider for providing deep insights on the technology during the interview.

\section{REFERENCES}

1 Karanjla Binalfar, Laxman Shankar, Goswami Saurajit. (2017). Blockchain Technology in India (opportunities and challenges). Gurugram, India: Deloitte.

2 Westland Duncan. (n.d.). Mobilizing blockcain technology for automotive industry.

3 Aayog), A. K. (2018, August 3). International block chain conference, Telangana. Hydrabad, Telengana.

4 Alejandro Ranchal Pedrosa UPMC - Sorbonne Université, P. F.-s.-Y.-S. (2018). ChargeItUp: On Blockchain-based technologies for Autonomous Vehicles. Reserachgate, DOI: 10.1109/Cybermatics_2018.2018.00278.

5 (2017). Blockchain for the Automotive Insustry , worldwide survey results. AMW World.

6 Blockchain Technolgy : Implications for operations and supply chain management. (n.d.). Supply Chain Management: an International Journal SCMO 92018-0309.R2.

7 Bohl Greg, D. J. (n.d.). PRIVATE BLOCKCHAINS IN AUTOMOTIVE SAFETY,.
8 Boyle Brandon . (2018). Retrieved from rolandberger.com/en/Publications/Blockchain'spotential-in-the-automotive-industry.html

9 Britchenko, D. o.-e. (2018). BLOCKCHAIN TECHNOLOGY INTO THE LOGISTICS SUPPLY CHAIN IMPLEMENTATION EFFECTIVENESS. Reserachgate.

10 Brody Paul, Schartau Philip . (2018). Industralising the blockchain for automotive. Earnst and Young.

11 Chuka Oham1, S. S. (2018). A Blockchain Based Liability Attribution Framework for Autonomous Vehicles. Reserachgate, arXiv:1802.05050v1 [cs.CR] 14 Feb 2018.

12 Colonna Simone, P. D. (2018). Blockchain application in automotive market-spare parts case study, Tesi di laurea Plytechnico Di Torino. webthesis.biblio.polito.it.

13 Dr Gareth R.T. White, U. o. (2017). Future Applications of Blockchain in Business and Management:a Delphi study. Reserachgate.

14 Fthi Arefayne Abadi, G. A. (2018). The Blockchain of Things, Beyond Bitcoin: A Systematic Review.

15 Gahathakurta, R. (2019). Blockchain based Automotive EDI system-concept Rahul Gahathakurta. Reserachgate, https://www.indrastra.com/2019/02/Blockchainbased-Automotive-EDISystem-.

16 https://appii.io/features/. (n.d.). Retrieved from https://appii.io/features/: https://appii.io/features/

17 https://asia.nikkei.com/Business/Automobile/ Hondaand-GM-join-in-smart-grid-and-electric-car-

research. (n.d.). Retrieved from https://asia.nikkei.com/Business/Automobile/Hondaand-GM-join-in-smart-grid-and-electric-car-research.

18 https://media.group. renault.com/ global/en-gb /media/pressreleases 194238. (n.d.). Retrieved from https://media.group.renault.com/global/en$\mathrm{gb} / \mathrm{media} /$ pressreleases/94238.

19 https://www. volvogroup.com/ en-en/news /2019. (n.d.). Retrieved from https://www.volvogroup.com/en-en/news/2019.

20 https://www. daimler.com / innovation/ blockchain2.html. (n.d.). Retrieved from https://www.daimler.com.

21 https://www.automotivetestingtechnologyinternationa l.com/news/rd/toyota-testing-electricity-system-thatuses-blockchain-technology.html. (n.d.). Retrieved from

https://www.automotivetestingtechnologyinternationa 1.com/news/rd/toyota-testing-electricity-system-thatuses-blockchain-technology.html

22 https://www.hyperledger.org. (2017, Aug 21). Retrieved https://www.hyperledger.org/about/members: https://www.hyperledger.org/about/members 


\section{International Journal of Engineering Applied Sciences and Technology, 2020 \\ Vol. 5, Issue 7, ISSN No. 2455-2143, Pages 83-101 \\ Published Online November 2020 in IJEAST (http://www.ijeast.com)}

23 https://www-03.ibm.com /press/us/en/ pressrelease/ 51147.wss. (n.d.). Retrieved from https://www03.ibm.com/press/us/en/pressrelease/51147.wss.

24 Huckle Steve, B. R. (2016). IOT,Blockchain and shared economy applications. Elsevier, doi: 10.1016/j.procs.2016.09.074 .

25 Ioannis Konstantinidis, G. S. (2018). Blockchain for Business Applications:A systematic literature review. Reserachgate, https://doi.org/10.1007/978-3-31993931-5_28.

26 Kouvelis Panos, D. L. (2019). Emerging Technology \& Advances in Supply Chain Finance \& Risk Management.

27 Lakhani, M. I. (2017, February). Technology ArticleThe truth about blockchain. Harward Business Review.

28 Ltd., P. T. (2019, 2 28). Blockchain 101.

29 Melanie Swan, P. U. (2018). Blockchain for Business: Next-Generation Enterprise Artificial. Researchgate.

30 (n.d.). NASSCOM Avasant India Blockchain report 2019. NASSCOM and Avasant.

31 Niti Aayog Recomends use of blockchain in land records, PDS and Healthcare. (2019, Aug 9). Hindustan Times. Hindustan Times.

32 PAULA FRAGA-LAMAS, T. M.-C. (2019). A Review on Blockchain Technologies for an Advanced and Cyber-Resilient Automotive Industry. IEEE Access, DOI: 10.1109/ACCESS.2019.2895302.

33 Schade Martin , Pytel Philipp. (2017). Blockchain technologies for automotive industry white paper by Ginkgo Mamagement consultancy. Ginkgo Mamagement consultancy.

34 Song Hua, E. Z. (2018). Apply blockchain technology to electric vehicle battery refueling. semantics scholar org.

35 Sowichaya Supranee, S. R. (2017). The Acceptance of the Application of Blockchain Technology in the
Supply Chain Process of the Thai Automotive Industry. (p. http://aisel.aisnet.org/iceb2017/30). Dubai , UAE: Association for Information Systems AIS Electronic Library (AISeL).

36 Sudhir Pai,Manuel Sevilla,Jerome Buvat,Ralph Schneider-Maul,Olivier Lise,Adrien Calvayrac, Tarun Karanam,Ramya Puttur. (2017). Digital blockchain in supply chain. CapGemini Research Institute.

37 White, D. G. (2017). Future Applications of Blockchain in Business and Management: a Delphi study.

38 Winson, J. (n.d.). https://www.jackvinson.com/blog/2018/5/7/combinin g-the-change-matrix-and-the-layers-of-resistance. Retrieved from https://www.jackvinson.com/blog/2018/5/7/combinin g-the-change-matrix-and-the-layers-of-resistance.

39 (12, Dec 2018). Year End Review 2018 :Niti Aayog. Press Information Bureau, Government of India.

40 Zibin Zheng, S. X.-s.-N. (2018). Blockchain challenges and opportunities: a survey. 14(4), DOI: 10.1504/IJWGS.2018.10016848.

41 ZIGURAT. (2018). https://www.ezigurat.com/innovation-school/blog/blockchainautomotive-industry/. Retrieved from https://www.ezigurat.com/innovation-school/blog/blockchainautomotive-industry/

\section{ANNEXTURES}

Table 6.1: Blockchain use cases by consultants

\begin{tabular}{|c|c|c|c|}
\hline S.No. & Application area & $\begin{array}{l}\text { Consultant } \\
\text { organization }\end{array}$ & Source \\
\hline 1 & $\begin{array}{l}\text { supply chain } \\
\text { (know your supplier) }\end{array}$ & Deloitte & \multirow[t]{6}{*}{$\begin{array}{l}\text { ( Woodward Michael et al. } \\
\text { 2018) }\end{array}$} \\
\hline 2 & $\begin{array}{l}\text { Inbound logistics and } \\
\text { smart manufacturing }\end{array}$ & Deloitte & \\
\hline 4 & $\begin{array}{l}\text { provenance, trace and } \\
\text { verify parts }\end{array}$ & Deloitte & \\
\hline 5 & connected supply chain & Deloitte & \\
\hline 6 & Targeted recall & Deloitte & \\
\hline 7 & Dealer and customer incentives & Deloitte & \\
\hline
\end{tabular}


International Journal of Engineering Applied Sciences and Technology, 2020

Vol. 5, Issue 7, ISSN No. 2455-2143, Pages 83-101

Published Online November 2020 in IJEAST (http://www.ijeast.com)

\begin{tabular}{|c|c|c|c|}
\hline 8 & Extended vehicle ledger & Deloitte & \\
\hline 9 & Odometer fraud prevention & Deloitte & \\
\hline \multirow[t]{2}{*}{10} & $\begin{array}{l}\text { Insurance contracts } \\
\text { (dynamic pricing) }\end{array}$ & Deloitte & \\
\hline & $\begin{array}{l}\text { Ride sharing and on } \\
\text { demand mobility service(Maas) }\end{array}$ & & \\
\hline 11 & Auto leasing and finance & Deloitte & \\
\hline 12 & $\begin{array}{l}\text { connected services } \\
\text { (Paying for parking etc.) }\end{array}$ & Deloitte & \\
\hline 13 & Electric vehicle payments & Deloitte & \\
\hline 14 & Retail and CPG & Deloitte & \multirow[t]{5}{*}{ ( Karanjla Binalfar et al. 2017) } \\
\hline 15 & Digital supply chain (Oil and gas) & Deloitte & \\
\hline 16 & $\begin{array}{lll}\begin{array}{l}\text { Patient record } \\
\text { (healthcare) }\end{array} & \\
\end{array}$ & Deloitte & \\
\hline 17 & $\begin{array}{l}\text { Roaming fraud management } \\
\text { telecom) }\end{array}$ & Deloitte & \\
\hline 18 & Land registry & Deloitte & \\
\hline 19 & supply chain & AMW world & \multirow{4}{*}{$\begin{array}{l}\text { (Blockchain for the Automotive } \\
\text { Insustry, worldwide survey } \\
\text { results, 2017) }\end{array}$} \\
\hline 20 & $\begin{array}{lll}\begin{array}{l}\text { Software management } \\
\text { hacking protection }\end{array} & \text { smart car } \\
\end{array}$ & AMW world & \\
\hline 21 & safety of autonomous vehicles & AMW world & \\
\hline 22 & Dynamic car insurance & AMW world & \\
\hline 23 & leasing & GMC & \multirow[t]{6}{*}{ (Schade Martin et al. 2017) } \\
\hline 24 & Dynamic insurance & GMC & \\
\hline 25 & Vehicle ledger & GMC & \\
\hline & Smart assembly & GMC & \\
\hline 26 & Supply chain & GMC & \\
\hline 27 & Retail and CPG & GMC & \\
\hline 28 & Digital thread & CapGemini & \multirow[t]{11}{*}{ (Sudhir Pai,et al. 2017) } \\
\hline 29 & Production tracking & CapGemini & \\
\hline 30 & Tracking asset maintenance & CapGemini & \\
\hline 31 & Tracking recalled products & CapGemini & \\
\hline 32 & Tracking Provenance & CapGemini & \\
\hline 33 & Tracking asset conditions & CapGemini & \\
\hline 34 & Regulatory compliance & CapGemini & \\
\hline \multirow[t]{2}{*}{35} & Providing warranties & CapGemini & \\
\hline & Tracking critical parameters & & \\
\hline 36 & Retail & CapGemini & \\
\hline 37 & Supplier contract management & CapGemini & \\
\hline 38 & Shared leasing & AT Kearney & \multirow[t]{9}{*}{ (Mathur Manish et al. 2019) } \\
\hline 39 & Insurance & AT Kearney & \\
\hline 40 & Secure payments & AT Kearney & \\
\hline 41 & Sourcing and procurement & AT Kearney & \\
\hline 42 & $\begin{array}{llll}\begin{array}{l}\text { Traceability } \\
\text { components }\end{array} & \text { of products } & \text { and } \\
\end{array}$ & AT Kearney & \\
\hline 43 & Supply chain & AT Kearney & \\
\hline 44 & Smart contracts & AT Kearney & \\
\hline 45 & Bank guarantee & AT Kearney & \\
\hline 46 & Cross border payments & AT Kearney & \\
\hline 47 & shared fleets and fractional ownership & Ernst and Young & \multirow{3}{*}{$\begin{array}{l}\text { (Brody Paul, Schartau Philip, } \\
\text { 2018) }\end{array}$} \\
\hline 48 & $\begin{array}{l}\text { Segregated aggregates of Electric } \\
\text { vehicles }\end{array}$ & Ernst and Young & \\
\hline 49 & Mobility as service & Ernst and Young & \\
\hline
\end{tabular}


International Journal of Engineering Applied Sciences and Technology, 2020

Vol. 5, Issue 7, ISSN No. 2455-2143, Pages 83-101

Published Online November 2020 in IJEAST (http://www.ijeast.com)

\begin{tabular}{|c|c|c|c|}
\hline 50 & Smart Contracts & Ernst and Young & \multirow[t]{3}{*}{ ( Westland Duncan) } \\
\hline 51 & Fractional ownership & Ernst and Young & \\
\hline 52 & Supply chain & Ernst and Young & \\
\hline 53 & Digital identities of vehicles & Roland Berger & \multirow[t]{5}{*}{ (Boyle Brandon , 2018) } \\
\hline 54 & Car e- wallets & Roland Berger & \\
\hline 55 & Smart Contracts & Roland Berger & \\
\hline 56 & Secure communication & Roland Berger & \\
\hline 57 & Supply chain & Roland Berger & \\
\hline 58 & Biometric security & Accenture & \multirow[t]{2}{*}{ ( Borrows Maisieet al. 2017) } \\
\hline 59 & Smart Contracts & Accenture & \\
\hline 60 & Financial services & Accenture & (Meszaros Richard et al. 2016) \\
\hline 61 & e-KYC & Mckinsey & \multirow[t]{3}{*}{ (Higginson Matt et al.) } \\
\hline 62 & Fraud Preventions & Mckinsey & \\
\hline 63 & Insurance and Smart Contracts & Mckinsey & \\
\hline
\end{tabular}

Table 6.2: Blockchain use cases by researchers

\begin{tabular}{|c|c|c|}
\hline Sr.No. & Application area & Source \\
\hline 1 & Automotive safety/public safety & (Bohl Greg) \\
\hline 2 & Liability attribution of autonomous vehicles & \multirow{3}{*}{$\begin{array}{c}\text { (Chuka Oham1, } \\
\text { 2018) }\end{array}$} \\
\hline 3 & Dynamic insurance & \\
\hline 4 & Proof of Service & \\
\hline 5 & Supply chain & $\begin{array}{c}\text { (Chuka Oham1, } \\
\text { 2018) }\end{array}$ \\
\hline 6 & Asset registry & \multirow{8}{*}{$\begin{array}{c}\text { (Melanie Swan, } \\
\text { 2018) }\end{array}$} \\
\hline 7 & Real time valuations & \\
\hline 8 & Smart Contracts & \\
\hline 9 & Payment Channel & \\
\hline 10 & Vehicle ledger & \\
\hline 11 & Financing & \\
\hline 12 & Insurance & \\
\hline 13 & Legal & \\
\hline 14 & EV Charging & $\begin{array}{c}\text { (Alejandro Ranchal } \\
\text { Pedrosa UPMC - } \\
\text { Sorbonne } \\
\text { Université, 2018) }\end{array}$ \\
\hline 15 & Parts tracking & \multirow{4}{*}{$\begin{array}{c}\text { (Ioannis } \\
\text { Konstantinidis, } \\
2018 \text { ) }\end{array}$} \\
\hline & Cross border transactions & \\
\hline 16 & Energy & \\
\hline 17 & Data Storage & \\
\hline 18 & Battery swapping & \multirow[t]{2}{*}{ (Song Hua, 2018) } \\
\hline 19 & Smart Contracts & \\
\hline 20 & Transportation & \multirow{7}{*}{$\begin{array}{c}\text { (Fthi Arefayne } \\
\text { Abadi, 2018) }\end{array}$} \\
\hline 21 & Vehicle ledger for maintenance & \\
\hline 22 & Automotive software update & \\
\hline 23 & Vehicle diagnosis & \\
\hline 24 & Transactive energy & \\
\hline 25 & Smart cities and home & \\
\hline 26 & Drones and robots & \\
\hline
\end{tabular}


International Journal of Engineering Applied Sciences and Technology, 2020

Vol. 5, Issue 7, ISSN No. 2455-2143, Pages 83-101

Published Online November 2020 in IJEAST (http://www.ijeast.com)

\begin{tabular}{|c|c|c|}
\hline 27 & Manufacturing & \\
\hline 28 & Supply chain & $\begin{array}{c}\text { (Kouvelis Panos, } \\
\text { 2019) }\end{array}$ \\
\hline 29 & Logistics & \multirow[t]{6}{*}{ (Britchenko, 2018) } \\
\hline 30 & Smart contract & \\
\hline 31 & Anti-counterfeit products & \\
\hline 32 & Transparency in supply chain, & \\
\hline 33 & Product safety & \\
\hline 34 & Food safety & \\
\hline 35 & Supply chain & \multirow{3}{*}{$\begin{array}{c}\text { (Gahathakurta, } \\
\text { 2019) }\end{array}$} \\
\hline 36 & Transparency & \\
\hline 37 & Cost rollup & \\
\hline 38 & Parts traceability & \multirow{13}{*}{$\begin{array}{c}\text { (Colonna Simone, } \\
\text { 2018) }\end{array}$} \\
\hline 39 & Connected supply chain & \\
\hline 40 & Targeted recall & \\
\hline 41 & Dealer and customer incentives, & \\
\hline 42 & Extended vehicle ledger & \\
\hline 43 & Odometer fraud & \\
\hline 44 & Ride sharing, & \\
\hline 45 & Dynamic insurance & \\
\hline 46 & Auto leasing and finance & \\
\hline 47 & Connected services & \\
\hline 48 & Electric vehicle charging & \\
\hline 49 & $3 \mathrm{D}$ printing & \\
\hline 50 & Counterfeited product & \\
\hline 51 & Smart contracts & \multirow{6}{*}{$\begin{array}{c}\text { (Michael Crosby (et } \\
\text { al. 2018) }\end{array}$} \\
\hline 52 & Financial markets & \\
\hline 53 & Token economy & \\
\hline 54 & Insurance and ledger & \\
\hline 55 & Data storage and sharing & \\
\hline 56 & Anti-counterfeit operations & \\
\hline 57 & Global supply chain management & \multirow{4}{*}{$\begin{array}{c}\text { (Dr Gareth R.T. } \\
\text { White, 2017) }\end{array}$} \\
\hline 58 & Certification of product quality & \\
\hline 59 & Verified consumer review & \\
\hline 60 & Data recording and storage & \\
\hline 61 & Autopay & \multirow{3}{*}{$\begin{array}{c}\text { (Huckle Steve, } \\
\text { 2016) }\end{array}$} \\
\hline 62 & Smart contracts & \\
\hline 63 & Digital right management & \\
\hline 64 & Smart manufacturing & \multirow{13}{*}{$\begin{array}{l}\text { (PAULA FRAGA- } \\
\text { LAMAS, 2019) }\end{array}$} \\
\hline 65 & Odometer fraud & \\
\hline 66 & Digital retailing and customer personalized experience & \\
\hline 67 & Claim processing & \\
\hline 68 & Usage based insurance & \\
\hline 69 & Maas & \\
\hline 70 & Peer to Peer lending leasing financing & \\
\hline 71 & Connected services & \\
\hline 72 & Connected vehicles & \\
\hline 73 & Smart charging services & \\
\hline 74 & Autonomous self-driving vehicles & \\
\hline 75 & Forensics & \\
\hline 76 & Extended global vehicle ledger & \\
\hline
\end{tabular}

Table 6.3: Blockchain use cases by Auto Companies 
International Journal of Engineering Applied Sciences and Technology, 2020

Vol. 5, Issue 7, ISSN No. 2455-2143, Pages 83-101

Published Online November 2020 in IJEAST (http://www.ijeast.com)

\begin{tabular}{|c|c|c|c|}
\hline $\begin{array}{c}\text { Sr.N } \\
\text { o. }\end{array}$ & Application area & Auto Company & Source \\
\hline 1 & $\begin{array}{c}\text { Contract } \\
\text { Management }\end{array}$ & \multirow[t]{4}{*}{$\begin{array}{l}\text { Mercedes-Benz } \\
\text { Daimler }\end{array}$} & \multirow[t]{4}{*}{$\begin{array}{l}\text { (https://www. daimler.com / innovation/ } \\
\text { blockchain-2.html, n.d.) }\end{array}$} \\
\hline 2 & Maas & & \\
\hline 3 & $\begin{array}{c}\text { Regulatory } \\
\text { Documentation }\end{array}$ & & \\
\hline 4 & Tokenization & & \\
\hline 5 & $\begin{array}{l}\text { Supply chain - } \\
\text { cobalt }\end{array}$ & Ford & \multirow{3}{*}{ (ZIGURAT, 2018) } \\
\hline 6 & $\begin{array}{l}\text { Odometer fraud } \\
\text { prevention }\end{array}$ & Volkswagen & \\
\hline 7 & Supply chain & Hyundai & \\
\hline 8 & $\begin{array}{l}\text { Cobalt mining and } \\
\text { supply chain }\end{array}$ & Volvo & $\begin{array}{l}\text { (https://www. volvogroup.com/ en-en/news } \\
\qquad / 2019, \text { n.d.) }\end{array}$ \\
\hline 9 & $\begin{array}{l}\text { EV smart grid } \\
\text { interoperability }\end{array}$ & $\begin{array}{l}\text { GM , Honda, } \\
\text { Toyota }\end{array}$ & $\begin{array}{c}\text { (https://asia.nikkei.com/Business/Automobile/ } \\
\text { Honda-and-GM-join-in-smart-grid-and-electric- } \\
\text { car-research, n.d.) } \\
\text { (https://www.automotivetestingtechnologyinter } \\
\text { national.com/news/rd/toyota-testing-electricity- } \\
\text { system-that-uses-blockchain-technology.html, } \\
\text { n.d.) }\end{array}$ \\
\hline 10 & $\begin{array}{l}\text { Supply chain } \\
\text { Financing }\end{array}$ & Mahindra & $\begin{array}{c}\text { (https://www-03.ibm.com /press/us/en/ } \\
\text { pressrelease/ 51147.wss, n.d.) }\end{array}$ \\
\hline 11 & $\begin{array}{l}\text { Self-Driving Car } \\
\text { (MOBI initiative) }\end{array}$ & $\begin{array}{l}\text { GM, Renault, } \\
\text { BMW }\end{array}$ & $\begin{array}{c}\text { (https://media.group. renault.com/ global/en-gb } \\
\text { /media/pressreleases } / 94238, \text { n.d.) }\end{array}$ \\
\hline
\end{tabular}

Table 6.4: Inputs summary given by blockchain lead users

\begin{tabular}{|c|c|c|}
\hline Sr.No & Organization & Key inputs \\
\hline 1 & $\begin{array}{l}\text { Telecom } \\
\text { company (lead } \\
\text { user) }\end{array}$ & $\begin{array}{l}\text {-Forthcoming Regulation forced Telecom as TRAI has mandated distributed ledger } \\
\text { technology to stop unsolicited telemarketing calls and messages (to avoid spam and } \\
\text { subscribers convenience). } \\
\text {-Started Alone, now working as consortium } \\
\text {-No other fields are explored further }\end{array}$ \\
\hline 2 & $\begin{array}{l}\text { Company } \\
\text { Bangalore } \\
\text { (Service } \\
\text { provider) }\end{array}$ & $\begin{array}{l}\text { Key findings after interview revealed following } \\
\text { Organization Working on solutions with EY, KPMG for foreign clients (Auto and } \\
\text { Aviation sector) on } \\
\text {-Provenance of parts and supply chain smart contracts(customer preference as } \\
\text { primary reason ,transparency, liability) } \\
\text {-Connected car speed monitoring ( safety requirement as primary reason) } \\
\text {-Automated payments (customer preference as a reason) } \\
\text {-Software updates and ant hacking of CAN ( security, cost and convenience to } \\
\text { customer is a reason) }\end{array}$ \\
\hline 3 & $\begin{array}{l}\text { Company } 2 \\
\text { Delhi } \\
\text { (Technology } \\
\text { Consultant) }\end{array}$ & $\begin{array}{l}\text {-Working on Product for qualification and background verification. Market is big and } \\
\text { demanding a solution and hence they are developing a product }\end{array}$ \\
\hline 4 & $\begin{array}{l}\text { Company } 3 \\
\text { (blockchain } \\
\text { products) }\end{array}$ & $\begin{array}{l}\text {-Working on invoice discounting product. Market is big and demanding a solution and } \\
\text { hence they are developing the product }\end{array}$ \\
\hline 5 & $\begin{array}{l}\text { Company } 4 \\
\text { (blockchain } \\
\text { products) }\end{array}$ & $\begin{array}{l}\text {-Working of Land Registry, anti-counterfeiting solutions in pharma sector solutions } \\
\text { with Governments. Government is driving the initiative }\end{array}$ \\
\hline
\end{tabular}




\begin{tabular}{|l|l|l|}
\hline 6 & Company 6 & $\begin{array}{l}\text {-Weighed blockchain solution for traceability in organic food category, but after } \\
\text { studies pulled back as there was no customer pull (appreciation) in Indian consumers. } \\
\text { Hence will review the same later on. }\end{array}$ \\
\hline 7 & $\begin{array}{l}\text { Company } \\
\text { (consultant) }\end{array}$ & $\begin{array}{l}\text {-Working on supply chain projects for overseas clients. } \\
\text { - Market pull and ecosystem is needed for blockchain success as technology. }\end{array}$ \\
\hline
\end{tabular}

Table 8.3: Common use cases researchers and consultants

\begin{tabular}{|c|c|c|c|}
\hline Consultant & Frequency & Researchers & Frequency \\
\hline $\begin{array}{l}\text { Extended vehicle ledger/Digital } \\
\text { Identities of vehicle /track } \\
\text { assets/dynamic insurance } \\
\text { /maintenance and monitoring } \\
\text { /Record management }\end{array}$ & 6 & $\begin{array}{l}\text { Extended vehicle ledger/Digital } \\
\text { Identities of vehicle /track } \\
\text { assets/dynamic insurance } \\
\text { maintenance and monitoring } \\
\text { /Record management /real time } \\
\text { valuations/remote } \\
\text { diagnostics/proof of service }\end{array}$ & 10 \\
\hline Supply chain & 4 & Supply chain/transparency & 5 \\
\hline $\begin{array}{l}\text { Connected services/Car wallets } \\
\text { /Electric vehicle charging }\end{array}$ & 3 & $\begin{array}{c}\text { Connected services /Car } \\
\text { wallets /Electric vehicle } \\
\text { charging's/payment channels }\end{array}$ & 8 \\
\hline $\begin{array}{l}\text { Shared Fleets / fractional } \\
\text { ownership /Ride sharing } \\
\text { /shared leasing/MaaS }\end{array}$ & 5 & $\begin{array}{c}\text { Shared Fleets / fractional } \\
\text { ownership /Ride sharing /token } \\
\text { economy /peer to peer lending } \\
\text { /MaaS }\end{array}$ & 5 \\
\hline Provenance/trace/verify parts & 3 & Provenance/trace/verify parts & 6 \\
\hline $\begin{array}{c}\text { Inbound logistics/Smart } \\
\text { Manufacturing/Production } \\
\text { tracking/sourcing and } \\
\text { procurement }\end{array}$ & 4 & $\begin{array}{c}\text { Inbound logistics/Smart } \\
\text { Manufacturing/Production } \\
\text { tracking/sourcing and } \\
\text { procurement }\end{array}$ & 3 \\
\hline $\begin{array}{l}\text { Connected supply chain/Digital } \\
\text { thread }\end{array}$ & 2 & $\begin{array}{c}\text { Connected supply chain/Digital } \\
\text { thread/ /auto cost rollup / } \\
\text { record management }\end{array}$ & 3 \\
\hline $\begin{array}{l}\text { Fraud prevention/Odometer } \\
\text { fraud prevention/Roaming } \\
\text { fraud } \\
\end{array}$ & 3 & $\begin{array}{l}\text { Fraud prevention/Odometer } \\
\text { fraud prevention }\end{array}$ & 2 \\
\hline EV segregated Aggregates & 1 & $\begin{array}{l}\text { EV segregated aggregates/ } \\
\text { battery swapping }\end{array}$ & 2 \\
\hline $\begin{array}{c}\text { Secure payments/bank } \\
\text { guarantee/Cross Border } \\
\text { Payments/ Automatic } \\
\text { transactions }\end{array}$ & 2 & $\begin{array}{c}\text { Secure payments/bank } \\
\text { guarantee/Cross Border } \\
\text { Payments/ Automatic } \\
\text { transactions }\end{array}$ & 1 \\
\hline $\begin{array}{l}\text { Targeted recall /Tracking } \\
\text { recalled products }\end{array}$ & 2 & $\begin{array}{l}\text { Targeted recall /Tracking } \\
\text { recalled products }\end{array}$ & 1 \\
\hline $\begin{array}{l}\text { Land registry(asset } \\
\text { registry)/biometric registry }\end{array}$ & 2 & $\begin{array}{l}\text { Land registry(asset } \\
\text { registry)/Biometrics security }\end{array}$ & 1 \\
\hline Smart car hacking protection & 1 & $\begin{array}{l}\text { Automatic software update/ } \\
\text { smart car antihacking }\end{array}$ & 2 \\
\hline Safety of Autonomous vehicles & 1 & $\begin{array}{l}\text { Secure communication in } \\
\text { autonomous cars/Safety of } \\
\text { Autonomous vehicles }\end{array}$ & 2 \\
\hline Financial services & 1 & finance /financial markets & 2 \\
\hline Regulatory compliance & 1 & Regulatory compliance /legal & 1 \\
\hline Providing warranties & 1 & Providing warranties/claim & 1 \\
\hline
\end{tabular}


International Journal of Engineering Applied Sciences and Technology, 2020

Vol. 5, Issue 7, ISSN No. 2455-2143, Pages 83-101

Published Online November 2020 in IJEAST (http://www.ijeast.com)

\begin{tabular}{|c|c|c|c|}
\hline & & processing & \\
\hline Retail & 1 & Retail /digital retailing & 1 \\
\hline $\begin{array}{c}\text { Dealer and Customer } \\
\text { incentives }\end{array}$ & 1 & $\begin{array}{c}\text { Dealer and customer } \\
\text { incentive's }\end{array}$ & 1 \\
\hline
\end{tabular}

Table 8.4: Analysis of Telecommunication use of blockchain to verify list of tele callers to stop unsolicited calls and message

\begin{tabular}{|c|c|}
\hline Pot of Gold & Verified list of tele callers. \\
\hline Broken limbs & Revenue loss as many tele callers will be screened out, cost involved. \\
\hline Mermaid & Non fulfilment of regulation will throw companies out of business. \\
\hline Alligator & $\begin{array}{c}\text { No such initiative by telecom companies. Stopping unsolicited calls was } \\
\text { thought as loss of revenue as such tele callers would move to other service } \\
\text { providers. }\end{array}$ \\
\hline Business Scenario & $\begin{array}{c}\text { Forthcoming Regulation forced telecom companies to go for blockchain. } \\
\text { Key insight }\end{array}$ \\
\hline
\end{tabular}

Table 8.5: Analysis of Software company use case of Provenance of parts and supply chain, smart contracts for foreign clients in Auto and Aerospace.

\begin{tabular}{|c|c|}
\hline Pot of Gold & $\begin{array}{c}\text { Complete traceability of parts, Liability attribution,-Targeted recall, } \\
\text { transparency in contracts and penalties }\end{array}$ \\
\hline Broken limbs & \multicolumn{1}{c|}{ Cost involved } \\
\hline Mermaid & $\begin{array}{c}\text {---- } \\
\text { Alligator } \\
\text { of recall, Difficult to impose penalties on suppliers in case of contract breach. }\end{array}$ \\
\hline Business Scenario & $\begin{array}{c}\text { Customer preference for transparency, liability laws are primary reasons for its } \\
\text { implementation in overseas markets. Auto industry is not coming forward in } \\
\text { India for this initiative as liability laws and customer preference are not strong } \\
\text { enough. }\end{array}$ \\
\hline Key insight & $\bullet \quad \begin{array}{c}\text { Market and stringent liability laws are forcing organizations to have } \\
\text { blockchain based solutions. }\end{array}$ \\
& $\bullet \quad \begin{array}{c}\text { Consortium based models are used } \\
\text { No such initiative by Auto OEMs in India }\end{array}$ \\
\hline
\end{tabular}

Table 8.6: Analysis of Software company use case of connected car speed monitoring for overseas clients in Auto Sector

\begin{tabular}{|c|c|}
\hline Pot of Gold & Comply with local traffic requirements \\
\hline Broken limbs & Cost involved \\
\hline Mermaid & ---- \\
\hline Alligator & Local Regulations will not allow sale of vehicles without such feature. \\
\hline Business Scenario & Stringent regulation by local authorities \\
\hline Key insight & $\begin{array}{l}\text { - Safety requirement by local authorities is the prime reason for adopting the } \\
\text { solution } \\
\text { - No such initiatives by local authorities or Auto OEMs in India }\end{array}$ \\
\hline
\end{tabular}

Table 8.7: Analysis of Software company use case of automated payments in cars for foreign clients

\begin{tabular}{|c|c|}
\hline Pot of Gold & Customer will prefer vehicles with such solutions. \\
\hline Broken limbs & Cost involved. \\
\hline Mermaid & ---- \\
\hline Alligator & Customers will not buy the vehicles without such feature. \\
\hline Business Scenario & Customers are aware about solutions and are demanding the feature. \\
\hline Key insight & - Customer preference is the primary reason for such solution and also \\
\hline
\end{tabular}




\begin{tabular}{|l|l|}
\hline & $\begin{array}{l}\text { ecosystem exists in overseas markets. } \\
\text { • No such initiative in India by Auto OEMs, lack of ecosystem. }\end{array}$ \\
\hline
\end{tabular}

Table 8.8: Analysis of Software Company use case of Software updates and anti-hacking of Connected Area network

\begin{tabular}{|c|c|}
\hline Pot of Gold & $\begin{array}{c}\text { Customer will prefer vehicles with such solutions, Liability avoidance for OEM } \\
\text { as the ledger helps in Court of Law in case of unforeseen events. }\end{array}$ \\
\hline Broken limbs & Cost involved. \\
\hline Mermaid & $\begin{array}{c}\text { Customers will not buy the vehicles without such feature and competitor may } \\
\text { adopt the feature. Liability threat on vehicle manufacturer .Huge cost of } \\
\text { updating the software. }\end{array}$ \\
\hline Alligator & $\begin{array}{c}\text { Customers are aware and demanding, Laws are stringent and litigations are } \\
\text { costly, }\end{array}$ \\
\hline Business Scenario & $\begin{array}{c}\text { Customer preference and avoidance of liability is the primary reason for } \\
\text { OEMs to prefer block chain based solutions. } \\
\text { No such initiative in India by auto OEMs. }\end{array}$ \\
\hline Key insight
\end{tabular}

Table 8.9: Analysis of Software company 2 use case of Qualification and background verification platform

\begin{tabular}{|c|c|}
\hline Pot of Gold & Revenue through new product \\
\hline Broken limbs & Cost involved. \\
\hline Mermaid & ---- \\
\hline Alligator & Someone else wins the potential market. \\
\hline Business Scenario & $\begin{array}{c}\text { No such solution in the market, there is potential for such product that industry } \\
\text { might need. }\end{array}$ \\
\hline Key insight & Market driven product as market is big and demanding a solution. \\
\hline
\end{tabular}

Table 8.10: Analysis of Analysis of Software company 3 use case of invoice discounting product

\begin{tabular}{|c|c|}
\hline Pot of Gold & New market. \\
\hline Broken limbs & Cost involved. \\
\hline Mermaid & ---- \\
\hline Alligator & Someone else wins the potential market. \\
\hline Business Scenario & Industry desperately need such product. No regulation restricts the product. \\
\hline Key insight & $\bullet \quad$ Market driven as market is big and demanding a solution. \\
\hline
\end{tabular}

Table 8.11: Analysis of Retail company use case of blockchain solution in organic food category

\begin{tabular}{|c|c|}
\hline Pot of Gold & Interested customers. \\
\hline Broken limbs & Cost involved. \\
\hline Mermaid & No USP. \\
\hline Alligator & Someone else win the business. \\
\hline Business Scenario & $\begin{array}{c}\text { After detailed survey found that customers are not aware and are not } \\
\text { appreciating such products (price still dominates the market) }\end{array}$ \\
\hline Key insight & Project was aborted in absence of customer demand for such solutions \\
\hline
\end{tabular}

Table 8.12: Analysis of Global Service Provider use case of supply chain projects for overseas clients

\begin{tabular}{|c|c|}
\hline Pot of Gold & Increased efficiencies. \\
\hline Broken limbs & Cost involved. \\
\hline Mermaid & ---- \\
\hline Alligator & No improvements over baselines. \\
\hline Business Scenario & High pressures on profit margins is pushing such solutions. \\
\hline Key insight & $\bullet \quad$ Ecosystem is needed for success of this technology, even foreign players \\
\hline
\end{tabular}




\begin{tabular}{|l|l|}
\hline & $\begin{array}{l}\text { struggle in absence of supportive ecosystem Hence to have success either } \\
\text { enterprise have less dependence on stakeholders, or are not dependent on } \\
\text { ecosystem or they go for consortium model to influence stakeholders. } \\
\text { Auto industry in India is silent }\end{array}$ \\
\hline
\end{tabular}

Table 8.3.1: Use case analysis of extended vehicle ledger/Digital Identities of vehicle/track assets/dynamic insurance maintenance and monitoring /Record management/real time valuations/remote diagnostics/proof of service

\begin{tabular}{|c|c|}
\hline Pot of Gold & $\begin{array}{l}\text { Customer satisfaction through convenience, transparency and hence upper edge } \\
\text { in the market. }\end{array}$ \\
\hline Broken limbs & Cost of development and implementation. \\
\hline Mermaid & 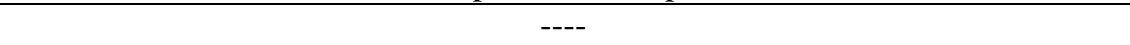 \\
\hline Alligator & Market will be lost if others implement the same solution. \\
\hline Business Scenario & $\begin{array}{l}\text { No such initiative in India by automakers or service providers like insurance } \\
\text { companies. No regulations by government to have distributed ledger } \\
\text { technology. No market pull or customer demand. Consortium model will be } \\
\text { needed. }\end{array}$ \\
\hline Conclusion & $\begin{array}{l}\text { Future use case and hence keep a watch and park the use case, review after } 3 \\
\text { years. }\end{array}$ \\
\hline
\end{tabular}

Table 8.3.2: Use case analysis of Supply chain solution.

\begin{tabular}{|c|c|}
\hline Pot of Gold & Streamlined supply chain, cost efficiency. \\
\hline Broken limbs & Cost of development and implementation. \\
\hline Mermaid & Credit policy is beneficial to auto companies. \\
\hline Alligator & Rate of improvement in supply chain efficiencies and effectiveness will be less. \\
\hline Business Scenario & $\begin{array}{l}\text { Neither a customer requirement, nor a regulatory requirement... Consortium } \\
\text { model will be needed to implement this initiatives with supplier. Hence can be } \\
\text { taken as an initiative at SIAM level. }\end{array}$ \\
\hline Conclusion & $\begin{array}{l}\text { Implement other initiative first. } \\
\text { Initiative that can be pursued at consortium level (SIAM) as it will benefit all } \\
\text { industry players. Review after } 3 \text { yrs.' }\end{array}$ \\
\hline & Table 8.3.3: Use case analysis of connected services (Car wallets/EV charging \\
\hline Pot of Gold & $\begin{array}{l}\text { Customer satisfaction through convenience, transparency and hence upper edge } \\
\text { in the market. }\end{array}$ \\
\hline Broken limbs & Cost of development and implementation. \\
\hline Mermaid & 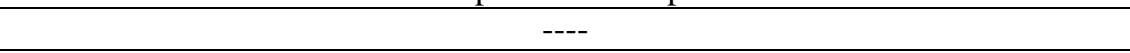 \\
\hline Alligator & Market will be lost if others implement the same. \\
\hline Business Scenario & $\begin{array}{l}\text { Neither a customer requirement, nor a regulatory requirement. Other options } \\
\text { like RFID tags coupled with e-wallets are available in the market. There is no } \\
\text { consumer awareness and pull for blockchain model. Ecosystem related } \\
\text { regulations are not available. } \\
\text { The trend might be relevant after some time by the time connected vehicles } \\
\text { becomes a necessity. }\end{array}$ \\
\hline Conclusion & $\begin{array}{c}\text { Review the use case after 2-3 yrs. Strategic collaboration with e-wallet } \\
\text { company can be done if regulation comes. }\end{array}$ \\
\hline
\end{tabular}

Table 8.3.4: Use case analysis of shared Fleets / fractional ownership /Ride sharing /token economy /peer to peer lending /MaaS.

\begin{tabular}{|c|c|}
\hline Pot of Gold & Increased sales due to unique feature. \\
\hline Broken limbs & Cost of development and implementation. \\
\hline Mermaid & Market will be lost if others implement the same. \\
\hline Alligator & $\begin{array}{c}\text { Not a current market demand, neither a regulation. This is a future use case, not } \\
\text { even implemented in mature markets. No such business visibility in next three } \\
\text { Business Scenars. }\end{array}$ \\
\hline Conclusion & Review the use case after 5 yrs. \\
\hline
\end{tabular}


International Journal of Engineering Applied Sciences and Technology, 2020

Vol. 5, Issue 7, ISSN No. 2455-2143, Pages 83-101

Published Online November 2020 in IJEAST (http://www.ijeast.com)

Table 8.3.5: Use case analysis of provenance/trace/verify parts

\begin{tabular}{|c|c|}
\hline Pot of Gold & Traceability of parts. \\
\hline Broken limbs & Cost of development and implementation. \\
\hline Mermaid & 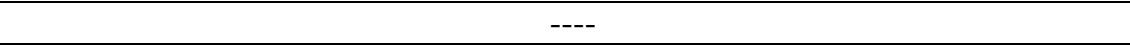 \\
\hline Alligator & $\begin{array}{l}\text { Difficulty to prove traceability of parts fitted at manufacturing plants premises } \\
\text { and after sales during service. After sales market that is filled with counterfeited } \\
\text { product remains untapped }\end{array}$ \\
\hline Business Scenario & Industry is not yet ready with basic Industry 4 infrastructure \\
\hline Conclusion & $\begin{array}{l}\text { Review after } 2-3 \text { yrs. to take traceability on block chain along with parts fitted } \\
\text { at dealer end to cover the risk imposed leftover post sales portion as well as to } \\
\text { tap the full potential of spare part market. }\end{array}$ \\
\hline
\end{tabular}

Table 8.3.6: Use case analysis of inbound logistics/Smart Manufacturing/Production tracking/sourcing and procurement/Connected supply chain

\begin{tabular}{|c|c|}
\hline Pot of Gold & Reduced cost, improved efficiencies and Quality. \\
\hline Broken limbs & Cost of development and implementation. \\
\hline Mermaid & ---- \\
\hline Alligator & $\begin{array}{c}\text { Rate of improvements in terms of efficiencies, Quality remains low. } \\
\text { Business Scenario } \\
\text { tools like JIT/ Kanban are under progress. Also this case needs infrastructural } \\
\text { support like IOT sensors, scanners etc. Consortium model will be beneficial and } \\
\text { supply chain solutions on blockchain goes hand in hand with smart } \\
\text { manufacturing. }\end{array}$ \\
\hline Conclusion & $\begin{array}{c}\text { Review the use case after 2-3 yrs. } \\
\end{array}$ \\
\hline
\end{tabular}

Table 8.3.7: Use case analysis of Targeted recall /Tracking recalled products

\begin{tabular}{|c|c|}
\hline Pot of Gold & Targeted vehicles during recall. \\
\hline Broken limbs & Cost of development and implementation. \\
\hline Mermaid & 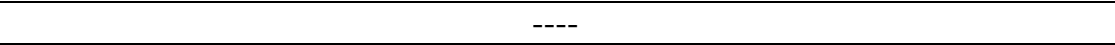 \\
\hline Alligator & $\begin{array}{l}\text { Difficulty to prove traceability of parts fitted at plants and after sales during } \\
\text { service. }\end{array}$ \\
\hline Business Scenario & Industry is not yet ready with basic Industry 4 infrastructure \\
\hline Conclusion & $\begin{array}{l}\text { Review after } 2-3 \text { yrs. to take traceability on block chain along with parts fitted } \\
\text { at dealer end to cover the risk imposed leftover post sales portion as well as to } \\
\text { tap the full potential of spare part market. }\end{array}$ \\
\hline
\end{tabular}

Table 8.3.8: Use case analysis of asset registry

\begin{tabular}{|c|c|}
\hline Pot of Gold & Cost of development and implementation. \\
\hline Broken limbs & ---- \\
\hline Mermaid & --- \\
\hline Alligator & \begin{tabular}{c}
--- \\
\hline Business Scenario
\end{tabular} \\
\hline Conclusion & $\begin{array}{c}\text { No such regulation/rule that mandates distributed ledger. This will be purely } \\
\text { depending upon future govt. regulation }\end{array}$ \\
\hline
\end{tabular}

Table 8.3.9: Use case analysis of automatic software update/ smart car antihacking. \begin{tabular}{l|l} 
Pot of Gold & Reduced cost of software update. Traceability of software's in vehicles. Fool
\end{tabular} 
International Journal of Engineering Applied Sciences and Technology, 2020

Vol. 5, Issue 7, ISSN No. 2455-2143, Pages 83-101

Published Online November 2020 in IJEAST (http://www.ijeast.com)

\begin{tabular}{|c|c|}
\hline & proofing \\
\hline Broken limbs & Cost of development and implementation \\
\hline Mermaid & ---- \\
\hline Alligator & $\begin{array}{c}\text { Increased cost with current Manual process where vehicle needs to be brought } \\
\text { to Dealership for software upgrade. Vehicle software remains vulnerable to } \\
\text { external threats. }\end{array}$ \\
\hline Business Scenario & $\begin{array}{c}\text { No regulation. Software content is increasing in vehicles with every product } \\
\text { launch in India }\end{array}$ \\
\hline Conclusion & This can be immediately reviewed for industrial feasibility and economic \\
viability with a dedicated CFT.
\end{tabular}

\begin{tabular}{|c|c|}
\hline \multicolumn{2}{c|}{ Table 8.3.10: Use case analysis of EV segregated aggregates } \\
\hline Pot of Gold & EV market \\
\hline Broken limbs & Cost of development and implementation. \\
\hline Mermaid & Competitors may develop. \\
\hline Alligator & $\begin{array}{c}\text { No such regulation from government. However due to complexity of Indian } \\
\text { market, government may float a regulation where EV batteries must have } \\
\text { provision for removal and re-fitment. }\end{array}$ \\
\hline Business Scenario & Keep close watch on regulation and the use case in 2-3 yrs. \\
\hline Conclusion & \\
\hline
\end{tabular}

Table 8.3.11: Use case analysis of secure payments/bank guarantee/Cross Border Payments/ Automatic transactions

\begin{tabular}{|c|c|}
\hline Pot of Gold & Ease of payments. \\
\hline Broken limbs & Development cost. \\
\hline Mermaid & ---- \\
\hline Alligator & ---- \\
\hline Business Scenario & No such demand. No regulations. Ecosystem is still a question mark. \\
\hline Conclusion & Review after 5 years. \\
\hline
\end{tabular}

\begin{tabular}{|c|c|}
\hline \multicolumn{2}{|c|}{ Table 8.3.12: Use case analysis of odometer fraud prevention } \\
\hline Pot of Gold & ---- \\
\hline Broken limbs & Development cost. \\
\hline Mermaid & ---- \\
\hline Alligator & If competitor markets as USP this might be a remote threat. \\
\hline Business Scenario & $\begin{array}{c}\text { No regulations. Market has already evolved through second hand car sellers. } \\
\text { Customer's preference can be checked during clinics. }\end{array}$ \\
\hline Conclusion & Review after 5 years. \\
\hline
\end{tabular}

Table 8.3.13: Use case analysis of dealer and customer incentives

\begin{tabular}{|c|c|}
\hline Pot of Gold & Loyal dealers and customers, repurchase \\
\hline Broken limbs & Development cost \\
\hline Mermaid & ---- \\
\hline Alligator & --- \\
\hline Business Scenario & $\begin{array}{c}\text { There are other tools available in Auto sector to have similar solution like CRM } \\
\text { and its full potential is yet to be realized. Dealer improvement programs are first } \\
\text { priority for auto companies in India. }\end{array}$ \\
\hline Conclusion & Review after 5 years. \\
\hline
\end{tabular}


International Journal of Engineering Applied Sciences and Technology, 2020

Vol. 5, Issue 7, ISSN No. 2455-2143, Pages 83-101

Published Online November 2020 in IJEAST (http://www.ijeast.com)

Table 8.3.14: Analysis and conclusion of block chain use case with business scenario

\begin{tabular}{|c|c|c|}
\hline $\begin{array}{c}\text { Use cases } \\
\text { Secure communication in autonomous cars/Safety of } \\
\text { Autonomous vehicles }\end{array}$ & $\begin{array}{c}\text { No forecast of Autonomous } \\
\text { vehicles in Indian Market }\end{array}$ & Review after 7 yrs. \\
\hline finance /financial markets & $\begin{array}{c}\text { Driven by Financial institutions. } \\
\text { Auto OEM can participate as auto } \\
\text { OEM partner }\end{array}$ & Review after 5 yrs. \\
\hline Regulatory compliance /legal & $\begin{array}{c}\text { No such regulations, alternate } \\
\text { methods are sufficient to address } \\
\text { current scenario }\end{array}$ & Review after 5 yrs. \\
\hline Providing warranties/claim processing & No such market pull & Review after 5 yrs. \\
\hline Smart Grid interoperability & $\begin{array}{c}\text { EV market is still a question mark } \\
\text { and the smart grid model is still a } \\
\text { research subject }\end{array}$ & Review after 7 yrs. \\
\hline Retail /digital retailing & No such market pull & Review after 7 yrs. \\
\hline
\end{tabular}

Fig 9: Roadmap of use cases for Indian Automotive industry

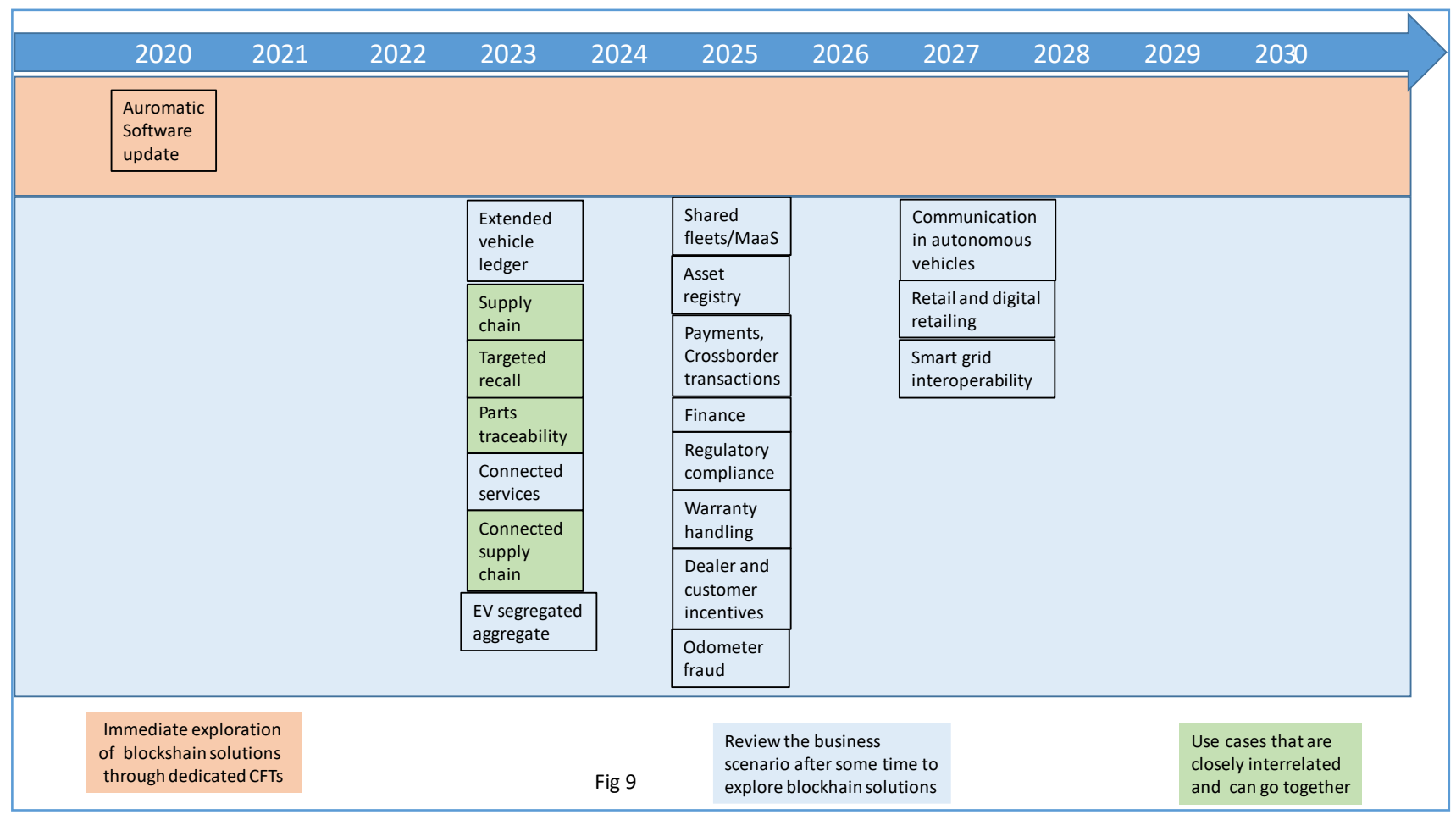

